\title{
Ascorbic acid of cowpea seeds under saline stress ${ }^{1}$
}

\author{
Luma Rayane de Lima Nunes ${ }^{2}$ (D), Paloma Rayane Pinheiro ${ }^{2}$ (D), Felipe Augusto \\ Sombra Cabral ${ }^{2}$ (D), João Batista da Silva² (D), Alek Sandro Dutra*2 (i)
}

\begin{abstract}
Salinity adversely affects plant growth and metabolism by triggering increased production of reactive oxygen species (ROS). Ascorbic acid (AsA) is known to protect organelles and cells against ROS by preventing accumulation. The objective of this study was to study the effects of AsA on cowpea beans under saline stress. Cowpea seeds of the cultivars (BRS Marataoã and Setentão) were conditioned at concentrations of 0.0 (control); $0.25 ; 0.50 ; 0.75$ and $1.00 \mathrm{mM} \mathrm{AsA}$ and seeded on paper towels,

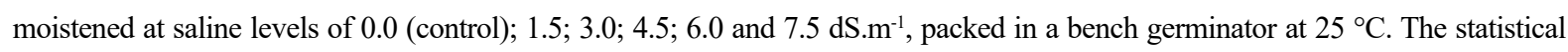
design adopted was a completely randomized $2 \times 5 \times 6$ factorial design (cultivar x ascorbic acid x saline levels) with four replicates of 50 seeds per treatment. The analyzed variables were percentage of germination, first germination count, germination speed index, shoot and root length, total seedling dry weight, and leaf and root electrolyte leakage. Ascorbic acid at concentrations of $0.50 \mathrm{mM}$ for BRS Marataoã and $0.75 \mathrm{mM}$ for the Setentão, enabled the development of more vigorous seedlings and the reduction of membrane damage caused by oxidative stress both in the absence of salt and at the saline levels tested, including the highest one.
\end{abstract}

Index terms: Vigna unguiculata L., oxidative stress, physiological potential, salinity.

\section{Ácido ascórbico em sementes de feijão-caupi sob estresse salino}

\begin{abstract}
RESUMO - A salinidade afeta negativamente o crescimento e o metabolismo vegetal, por desencadear o aumento da produção das espécies reativas de oxigênio (EROs). O ácido ascórbico (AsA) é conhecido por proteger organelas e células contra as EROs evitando seu acúmulo. Assim, objetivou-se estudar os efeitos do AsA em sementes de feijão-caupi submetidas ao estresse salino. As sementes de feijão-caupi das cultivares (BRS Marataoã e Setentão) foram condicionadas nas concentrações 0,0 (controle); 0,25 ; 0,50; 0,75 e 1,00 mM de AsA e semeadas em rolos de papel, umedecidos nos níveis salinos de 0,0 (controle); 1,$5 ; 3,0 ; 4,5 ; 6,0$ e $7,5 \mathrm{dS} . \mathrm{m}^{-1}$, acondicionados em germinador de bancada a $25^{\circ} \mathrm{C}$. O delineamento estatístico adotado foi o inteiramente casualizado em esquema fatorial $2 \times 5 \times 6$ (cultivar x concentrações de ácido ascórbico x níveis de salinidade) com quatro repetições de 50 sementes por tratamento. As variáveis analisadas foram porcentagem de germinação, primeira contagem de germinação, índice de velocidade de germinação, comprimento da parte aérea e da raiz, massa seca total da plântula e extravasamento de eletrólitos das folhas e da raiz. O ácido ascórbico nas concentrações de $0,50 \mathrm{mM}$ para o BRS Marataoã e 0,75 mM para o Setentão, possibilitou o desenvolvimento de plântulas mais vigorosas e a redução dos danos às membranas ocasionado pelo estresse oxidativo tanto na ausência de sal quanto para os níveis salinos testados, inclusive no mais elevado.
\end{abstract}

Termos para indexação: Vigna unguiculata L., extresse oxidativo, potencial fisiológico, salinidade.

\section{Introduction}

Cowpea [Vigna unguiculata (L.) Walp.] is an important source of protein for human consumption in the North and Northeast regions of Brazil because of its low cost (Freire Filho et al., 2011). It is grown by both subsistence farmers (and sold in small surplus volumes) and medium and large-scale producers that target the national and international markets (Freire et al., 2007). Under field conditions, vigorous plants and uniform stand are obtained not only through the choice of quality seeds, but also with some specific conditions of water availability, temperature, light and sowing depth (Mondo et al., 2010).

\footnotetext{
${ }^{1}$ Submitted on: 4/4/2019. Accepted for publication on: 9/11/2019.

${ }^{2}$ Centro de Ciências Agrárias, Departamento de Fitotecnia, Laboratório de Análise de Sementes, Universidade Federal do Ceará - Fortaleza, Ceará, Brasil.

*Corresponding author <alekdutra@ufc.br>
} 
An important factor affecting seeds is salinity, which may be present in irrigation water, in the soil or in both of them. Increased salinity interferes with growth medium, germination and seedling development. This is likely to be due to reduced water uptake by plants as a result of excess salts, leading to a reduction in soil water potential. Together with the toxic effects of ions on seed protoplasm, such reduction impairs germination and germination speed, and causes the formation of seedlings with reduced growth, characterized by decreased length and lower biomass accumulation (Conus et al., 2009).

Ionic effects result from high absorption of ions, especially $\mathrm{Na}^{+}$and $\mathrm{Cl}$, altering the ionic homeostasis of cells, which is essential for the activities of many cytosolic enzymes and for maintenance of cell membrane potential (Yu et al., 2012). Secondarily, salinity also induces oxidative stress by causing the accumulation of reactive oxygen species (ROS), such as hydrogen peroxide $\left(\mathrm{H}_{2} \mathrm{O}_{2}\right)$ and free radicals, superoxide $\left(\mathrm{O}_{2}^{-}\right)$and hydroxyl $(\mathrm{OH})$. At high concentrations, these species are extremely harmful to cells, causing oxidative damage to membrane lipids, proteins and nucleic acids (Xu et al., 2017).

To protect against ROS, plants have developed highly efficient defense mechanisms represented by antioxidant enzymes including superoxide dismutase, catalase and ascorbate peroxidase (Munné-Bosch et al., 2013). There are also non-enzymatic antioxidant protectors such as ascorbic acid (AsA), glutathione (GSH), $\alpha$-tocopherols, flavonoids, alkaloids, carotenoids, hormones and vitamins, which actively participate in the control of ROS in cells (Apel and Hirt, 2004).

In plants, ascorbate is the most important antioxidant and, in combination with other defense system components, it protects plants against oxidative damage resulting from aerobic metabolism, photosynthesis and a range of pollutants; it inhibits membrane peroxidation, thereby protecting cells from damage and delaying their senescence (Zhang, 2013).

Given the above, the objective of this research was to study the effects of ascorbic acid on the conditioning of cowpea seeds under saline stress.

\section{Material and Methods}

The experiment was conducted at the Seed Analysis Laboratory, Department of Plant Science, Center for Agrarian Sciences, Federal University of Ceará, Pici Campus, Fortaleza. It used cowpea seeds from the BRS Marataoã and Setentão genotypes. First, moisture content and thousand seed weight were determined for the seeds, as described by Brasil (2009).

The seeds were disinfected by soaking in a $70 \%(\mathrm{v} / \mathrm{v})$ alcohol solution with agitation for 30 seconds, followed by two quick washes with distilled water. Immediately after that, they were immersed in $2.5 \%$ (v/v) sodium hypochlorite solution for 2 minutes, washed with distilled water and dried on paper towels. Subsequently, the seeds were conditioned on paper towels $\left(\right.$ Germitest $\left.^{\mathbb{}}\right)$, moistened with ascorbic acid solution at concentrations of 0,$0 ; 0.25 ; 0.50 ; 0.75$ and 1.0 $\mathrm{mM}$, at a ratio of 2.5 times the substrate weight, for a period of 4 hours at $25^{\circ} \mathrm{C}$ (Brilhante et al., 2013).

The conditioned seeds were placed on paper towels, moistened with saline solution, at a ratio of 2.5 times the substrate weight. The solutions were adjusted to concentrations of 0.0 (control); $1.5 ; 3.0 ; 4.5 ; 6.0$ and $7.5 \mathrm{dS}^{-\mathrm{m}^{-1}}$ by dilution of sodium chloride $(\mathrm{NaCl})$ in distilled water based on the formula proposed by Richards (1954). For each treatment, 200 seeds were used; they were distributed into four paper towels, with 50 seeds each and placed in a bench germinator at $25^{\circ} \mathrm{C}$.

First count and final count of the germination test were performed on the fifth and eighth days after the test setup, respectively. Percentage of normal seedlings was determined using the definitions established in the Rules for Seed Testing (Brasil, 2009) as classification criteria. Normal seedling counts were performed on a daily basis to calculate the germination speed index proposed by Maguire (1962).

Shoot and main root growth analysis was performed eight days after setup of the germination test. Ten normal seedlings were selected per treatment for measurements aided by a ruler graduated in centimeters. Then, the seedlings were taken to a forced-air oven at a constant temperature of $65^{\circ} \mathrm{C}$ for 72 hours. Soon after that, they were weighed in a precision scale with three decimal places to measure dry phytomass, with results expressed in milligrams ${ }^{-1}$.

Membrane permeability was determined by electrolyte leakage on the eighth day after setup of the germination test. Leaf disks and roots of the middle and upper thirds of the root system were used; approximately 0.1 gram was selected and placed in test tubes containing $10 \mathrm{~mL}$ of distilled water. They were then closed and kept at rest for 24 hours at room temperature $\left(25^{\circ} \mathrm{C}\right)$. After this time, initial conductivity $(\mathrm{C} 1)$ was read using a properly calibrated bench conductivity meter. Subsequently, the tubes were subjected to a temperature of $80^{\circ} \mathrm{C}$ for 60 minutes in a water bath and, after cooling, final conductivity (C2) was measured. Relative permeability was calculated based on the $[\mathrm{C} 1 /(\mathrm{C} 1+\mathrm{C} 2)] \times 100$ ratio (Tarhanen et al., 1999).

The experiment was conducted in a completely randomized design, distributed in a triple factorial scheme 2 (genotypes) x 5 (ascorbic acid concentrations) x 6 (saline levels). Each treatment consists of four replications. Data underwent analysis of variance and then regression analysis at $5 \%$ significance level in the statistical software SISVAR ${ }^{\circledR}$ (Ferreira, 2000). Graphical representation of the results used the software Sigmaplot, version 12.5. 


\section{Results and Discussion}

The seeds presented different values for degree of moisture and thousand seed weight: $13.0 \%$ and $182.53 \mathrm{~g}$ for genotype BRS Marataoã, and $11.0 \%$ and $178.30 \mathrm{~g}$, for genotype Setentão, respectively.

According to the analysis of variance, there was a significant interaction between treatment with ascorbic acid
(AsA) and the presence of salt $(\mathrm{p} \leq 0.05)$, but there was no interaction between the tested genotypes (Table 1).

Germination of cowpea seeds was negatively influenced by salinity; in the absence of salt, germination was $95 \%$ for BRS Marataoã and $94 \%$ for Setentão. When subjected to $7.5 \mathrm{dS} . \mathrm{m}^{-1}$, these values decreased to $68 \%$ and $75 \%$, respectively, with the former being more sensitive to salinity (Figures 1A and 1B).

Table 1. Mean squared values and significance for the variables germination test $(\mathrm{G} \%)$, first germination count (FC\%), germination speed index (GSI), shoot length (SL) and root length (RL), whole seedling dry weight (SDW), leaf electrolyte leakage (LEL) and root electrolyte leakage (REL), under saline stress.

\begin{tabular}{|c|c|c|c|c|c|c|c|c|}
\hline \multirow{2}{*}{ F.V. } & \multicolumn{8}{|c|}{ Mean Squared Values of Variables } \\
\hline & $\mathrm{G}(\%)$ & $\mathrm{FC}(\%)$ & GSI & SL & RL & SDW & LEL & REL \\
\hline $\mathrm{Gt}$ & $183.75^{*}$ & $183.75^{* *}$ & $123.27^{* *}$ & $17.95^{* *}$ & $308.61^{*}$ & $0.00301^{*}$ & $5.82^{*}$ & $33.38^{*}$ \\
\hline AsA & $385.77^{*}$ & $385.77^{*}$ & $77.50^{* *}$ & $85.91^{* *}$ & $66.35^{* *}$ & $0.00122^{*}$ & $130.97^{*}$ & $631.71^{*}$ \\
\hline Sal & $1539.49^{*}$ & $1539.49^{*}$ & $98.99^{*}$ & $333.52^{*}$ & $732.88^{*}$ & $0.00248^{*}$ & $49.81^{*}$ & $16.63^{*}$ \\
\hline $\mathrm{Gt}^{*} \mathrm{AsA}$ & $72.87^{\mathrm{ns}}$ & $72.87^{\mathrm{ns}}$ & $18.98^{\mathrm{ns}}$ & $5.25^{\mathrm{ns}}$ & $29.95^{\mathrm{ns}}$ & $0.00091^{\mathrm{ns}}$ & $7.93^{\mathrm{ns}}$ & $9.92^{\text {ns }}$ \\
\hline $\mathrm{Gt}^{*} \mathrm{Sal}$ & $41.79^{\mathrm{ns}}$ & $41.79^{\mathrm{ns}}$ & $2.27^{\mathrm{ns}}$ & $7.47^{\mathrm{ns}}$ & $31.63^{\mathrm{ns}}$ & $0.00033^{\mathrm{ns}}$ & $10.76^{\mathrm{ns}}$ & $8.09^{\text {ns }}$ \\
\hline AsA*Sal & $51.61^{*}$ & $51.61^{* *}$ & $4.26^{* *}$ & $3.59^{* *}$ & $9.70^{* *}$ & $0.00009^{*}$ & $18.10^{* *}$ & $71.77^{*}$ \\
\hline $\mathrm{Gt}^{*} \mathrm{AsA} * \mathrm{Sal}$ & $13.26^{\mathrm{ns}}$ & $13.26^{\mathrm{ns}}$ & $1.75^{\mathrm{ns}}$ & $5.27^{\mathrm{ns}}$ & $5.19^{\text {ns }}$ & $0.000087^{\mathrm{ns}}$ & $4.43^{\mathrm{ns}}$ & $8.4^{* \mathrm{~ns}}$ \\
\hline Mean & 89.61 & 79.61 & 13.42 & 10.93 & 13.62 & 0.075 & 48.10 & 45.70 \\
\hline C.V. $(\%)$ & 1.73 & 1.95 & 3.36 & 4.12 & 1.01 & 1.88 & 0.98 & 1.42 \\
\hline
\end{tabular}

Gt: genotype; AsA: ascorbic acid concentrations; Sal: saline levels;

*Significant at $5 \%$;

**Significant at $1 \%$;

Ns: non-significant;

F.V: factor of variance.
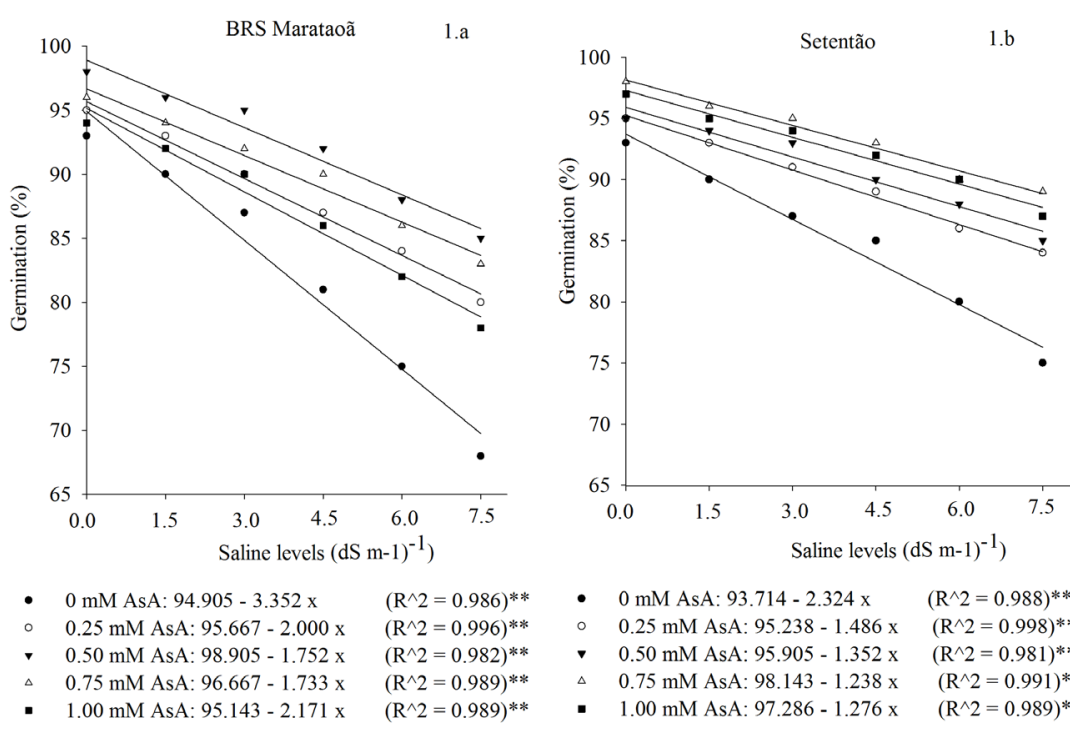

- 0 mM AsA: $93.714-2.324 x \quad\left(\mathrm{R}^{\wedge} 2=0.988\right)^{* *}$

$\circ \quad 0.25$ mM AsA: $95.238-1.486 \times \quad\left(\mathrm{R}^{\wedge} 2=0.998\right) * *$

- $\quad 0.50 \mathrm{mM}$ AsA: $95.905-1.352 \mathrm{x} \quad\left(\mathrm{R}^{\wedge} 2=0.981\right)^{* *}$

$\triangle \quad 0.75$ mM AsA: $98.143-1.238 \times \quad\left(\mathrm{R}^{\wedge} 2=0.991\right)^{* * *}$

- $1.00 \mathrm{mM}$ AsA: $97.286-1.276 \mathrm{x} \quad\left(\mathrm{R}^{\wedge} 2=0.989\right)^{* *}$

Figure 1. Germination of cowpea seeds at different saline levels and conditioned with ascorbic acid.

*Significant at $5 \%$;

**Significant at $1 \%$. 
These results corroborate those reported by Deuner et al. (2011), who found that, in the absence of salt, average seed germination of the cowpea genotypes was $93 \%$, with these values remaining until the $100 \mathrm{mM} \mathrm{NaCl}$ concentration (approximately $10 \mathrm{dS}^{-1} \mathrm{~m}^{-1}$ ). However, at higher concentrations, 150 and 200 $\mathrm{mM}$ (equivalent to 15 and $20 \mathrm{dS} . \mathrm{m}^{-1}$, respectively), there was a gradual reduction in germination, reaching values below $10 \%$ at the highest concentration tested for the genotypes Amendoim, Baio and Preto and $15 \%$ for the genotype Mosqueado. However, Ferreira et al. (2017) and Gomes et al. (2015) found no reduction in seed germination of bean (Phaseolus spp.) genotypes when under increasing saline levels.

For pigeon pea (Cajanus cajan), final seed germination in the absence of salinity reached $88 \%$, but it was reduced to $48 \%$ when subjected to $1.5 \mathrm{MPa} \mathrm{NaCl}$ (equivalent to $60 \mathrm{dS} . \mathrm{m}^{-1}$ ) (Pinheiro et al., 2013). The reduction in germination is an expected result because salinity has osmotic and ionic effects, which leads to reduction in water absorption and favors the entry of ions into the cell, and water restriction may be further intensified by sodium and chlorine accumulation near the rhizosphere (Carvalho et al., 2012).

The conditioning of cowpea seeds with ascorbic acid (AsA) increased seed germination percentage of the evaluated genotypes, reaching values of $85 \%$ and $89 \%$ for BRS Marataoã and Setentão, respectively, even when under a higher saline level $\left(7.5 \mathrm{dS} \cdot \mathrm{m}^{-1}\right)$. This increase may be due to the high endogenous concentration of ascorbic acid in seeds as a result of conditioning, thus enabling the promotion of gibberellin biosynthesis (Khan et al., 2011).

The genotypes presented different behaviors in response to the application of ascorbic acid against salinity; for BRS Marataoã, the concentration of $0.50 \mathrm{mM}$ AsA provided the highest values, with average germination higher than $90 \%$ until the level of. $4.5 \mathrm{dS} . \mathrm{m}^{-1}$. Germination was reduced as salinity increased: $85 \%$ of the seeds germinated at $7.5 \mathrm{dS.m}$ 1. This value is higher than the one found in seeds without AsA treatment and exposed to $4.5 \mathrm{dS} \cdot \mathrm{m}^{-1}(81 \%)$. For genotype Setentão, the best values were found at a concentration of $0.75 \mathrm{mM}$ AsA (Figures 1A and 1B).

Ascorbic acid regulates plant metabolism (Talla et al., 2011), and it is also involved in the growth process, i.e., embryogenesis, during seed development (Raza et al., 2013). However, when high rates are applied, germination may be interrupted or reduced, as reported by Ishibashi and IwayaInoue (2006) in wheat seeds when treated with 50 and 100 $\mathrm{mM}$ ascorbic acid.

The benefits of seed treatment with AsA in promoting germination in the face of salt stress have been reported by some authors, including Çavusoglu and Bilir (2015). They found an increase in germination as AsA concentrations increased in barley seeds, but they warn that AsA should only be applied when there is a stressful situation. Azooz and AlFredan (2009), in seeds of Vicia faba L. cv. Hassawi, detected reduced germination when different saline dilutions were used, but when the seeds were treated with $100 \mathrm{ppm}$ vitamin $\mathrm{C}$, these values were high. In soybean seeds, application of $400 \mathrm{ml} . \mathrm{L}^{-1}$ of AsA resulted in increased germination even when induced at $50 \mathrm{mM} \mathrm{NaCl}$, approximately $5.0 \mathrm{dS} . \mathrm{m}^{-1}$ (Dehghan et al., 2011).

As with the germination test, the first germination count test was influenced by saline and AsA concentrations (Table 1). Again, the treatment of seeds with ascorbic acid was effective in resisting salinity-induced damage; a concentration of 0.50 $\mathrm{mM}$ is recommended for genotype BRS Marataoã and $0.75 \mathrm{mM}$ for genotype Setentão (Figures 2A and 2B).

Saline stress was detrimental to cowpea seed germination for both genotypes, and there was a linear decrease as the saline levels in the substrate were increased. Deuner et al. (2011) found the same behavior in cowpea genotypes; they reported a delay and reduction in germination at concentrations equal to and above $50 \mathrm{mM} \mathrm{NaCl}$, while at higher concentrations (150 and $200 \mathrm{mM}$ ), the seeds had not yet germinated. In soybean seeds, first germination count was also negatively affected by salt stress (Soares et al., 2015). However, in snap bean, Gomes et al. (2015) reported no difference between the values found for the control and for the other saline treatments for this variable.

This reduction can be attributed to the high concentration of solutes in the solution because of the action of some ions, given the high levels of $\mathrm{Na}^{+}$and $\mathrm{Cl}^{-}$, and changes in the ration of $\mathrm{K}^{+}$and $\mathrm{At}^{+}$and other nutrients (Willadino and Camara, 2010).

As for germination speed index, speed was higher in the absence of salt and, as salinity increased, the seeds needed more time to soak and germinate (Figures $3 \mathrm{~A}$ and $3 \mathrm{~B}$ ).

Seeds that were conditioned with AsA soaked and germinated faster. In the Marataoã genotype, the germination speed index value was 13 for seeds that were not conditioned and not exposed to salinity. However, when conditioned, these values increased, reaching an average value of 18 at ascorbic acid concentration of $0.50 \mathrm{mM}$. Still at the same concentration, when the seeds were submitted to the highest saline level $\left(7.5 \mathrm{dS} . \mathrm{m}^{-1}\right)$, GSI was 11 , similar to the rate found in untreated seeds exposed to $4.5 \mathrm{dS} . \mathrm{m}^{-1}$ (Figure 3A). In genotype Setentão, the concentration of $0.75 \mathrm{mM}$ AsA led to the highest GSI values (Figure 3B). Ascorbic acid affects various physiological processes, including plant metabolic differentiation and increased availability of water and nutrients, thus enabling plants to be protected against environmental stresses such as salt stress (Khan et al., 2011).

The evaluation of seedling growth showed that cowpea 

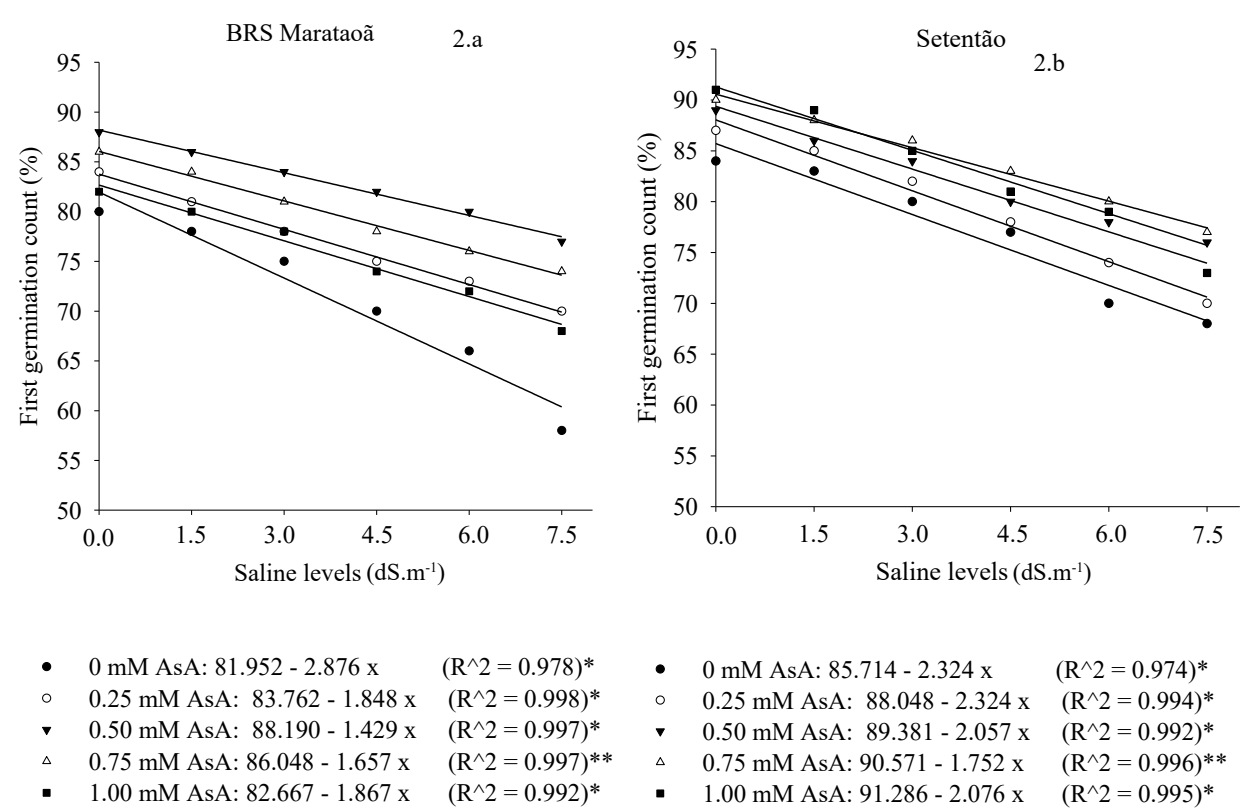

Figure 2. First germination count of cowpea seeds at different saline levels and conditioned with ascorbic acid.

*Significant at $5 \%$;

**Significant at $1 \%$.
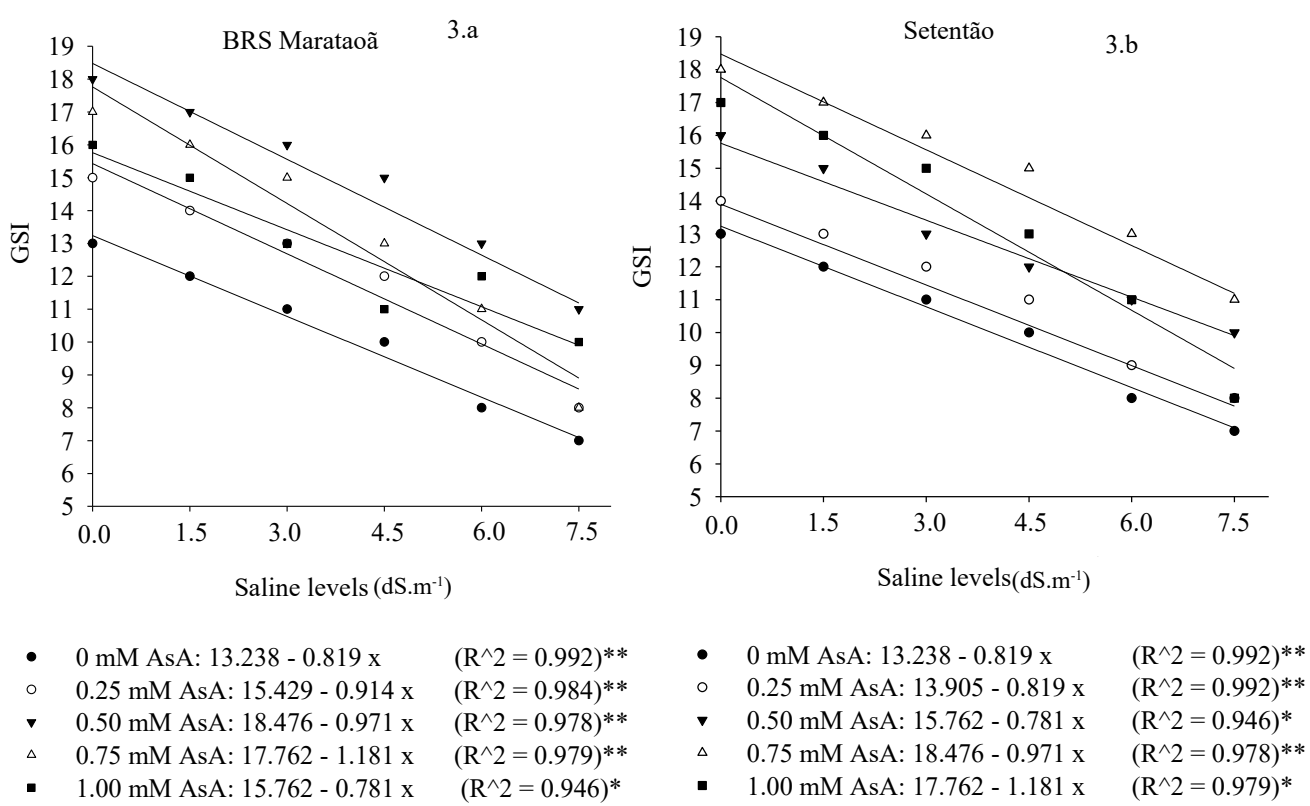

Figure 3. Germination speed index of cowpea seeds at different saline levels and conditioned with ascorbic acid. *Significant at $5 \%$;

** Significant at $1 \%$.

genotypes showed high sensitivity to saline environments, which directly interferes with shoot development (Figure 4).

The analysis of shoot length by adjusting the regression curves for the two evaluated genotypes, showed that they presented a similar tendency in response to the treatments being used. For measurements taken on seedlings without ascorbic acid treatment and subjected to increasing salt concentrations, there was a constant decrease for this variable, reaching the values of 5.70 and $5.50 \mathrm{~cm}$ for Marataoã and Setentão, respectively, at the level of $7.5 \mathrm{dS} . \mathrm{m}^{-1}$. In these environments, the high concentration of $\mathrm{Na}^{+}$and $\mathrm{Cl}^{-}$inside cells caused protein denaturation and membrane destabilization by 
reducing hydration of these macromolecules, thus impairing growth and development, mainly because of the reduction of cell water potential (Taiz et al., 2017).

However, seed conditioning with AsA at concentrations of 0.50 for BRS Marataoã and $0.75 \mathrm{mM}$ for Setentão provided higher seedling growth, which reached average values of $10.00 \mathrm{~cm}$ in both genotypes when exposed to the highest salinity level tested. Even when not subjected to saline stress, the treated seeds were more vigorous when compared to the untreated seeds, as shown by shoot length: for the genotype Marataoã, the values were $15.00 \mathrm{~cm}$ for the treated seeds but $13.50 \mathrm{~cm}$ for the untreated ones (Figure 4A). For genotype Setentão, these values were over 13.00 and $12.00 \mathrm{~cm}$ for treated and untreated seeds, respectively (Figure 4B).

Different studies have been carried out to evaluate the effects of salt on the initial seedling growth. Nascimento et al. (2017), working with lima bean, found an inversely proportional ratio between shoot length and increase of substrate salinity for the genotype Rosinha at a temperature of $25^{\circ} \mathrm{C}$, while, under the same conditions, genotypes Branca and Orelha de Vó were not influenced by the presence of $\mathrm{NaCl}$. In soybeans, decreases in seedling size were also reported as salt concentration increased, with the conventional genotype showing to be more sensitive and with more drastic reductions compared to the transgenic genotype. This interruption in plant growth is due to the high metabolic cost of energy the plants need to adapt to salinity
(Carvalho et al., 2012).

The benefits of ascorbic acid on shoot growth have been reported by some authors, including Gad El-Hak et al. (2012) on pea plants after spraying 200 ppm ascorbic acid on leaves. Dehghan et al. (2011), when treating DPX soybean seeds with $400 \mathrm{mg} . \mathrm{L}^{-1} \mathrm{AsA}$, found that seedlings that were induced to 50 $\mathrm{mM}$ saline stress had higher average length than seedlings from the control treatment (absence of salt and untreated seeds). The positive effect of ascorbic acid may be due to increased salinity tolerance as a result of its antioxidant effect (Dawood et al., 2017).

The analyzed factors also interfered with root growth of cowpea seedlings. For genotype BRS Marataoã, the highest values were found in seeds treated with $0.50 \mathrm{mM}$ AsA; even at the highest saline level $\left(7.5 \mathrm{dS} . \mathrm{m}^{-1}\right)$, this value was higher than the one found in the control treatment when exposed to $4.5 \mathrm{dS} \cdot \mathrm{m}^{-1}$. The same result was found for genotype Setentão in seeds treated with $0.75 \mathrm{mM}$ ascorbic acid. In both genotypes, the shortest root length was found in the absence of AsA (Figures 5A and 5B).

These results corroborate those found by other authors, including Dalchiavon et al. (2016), who found a reduction in root growth in common bean seeds, as the saline levels were increased, with values ranging from $11.90 \mathrm{~cm}$ for control and $9.00 \mathrm{~cm}$ for the highest salt concentration tested. Maia et al. (2012) found $56 \%$ and $25 \%$ reductions in root length of cultivars Pitiúba and Pérola under the highest salt
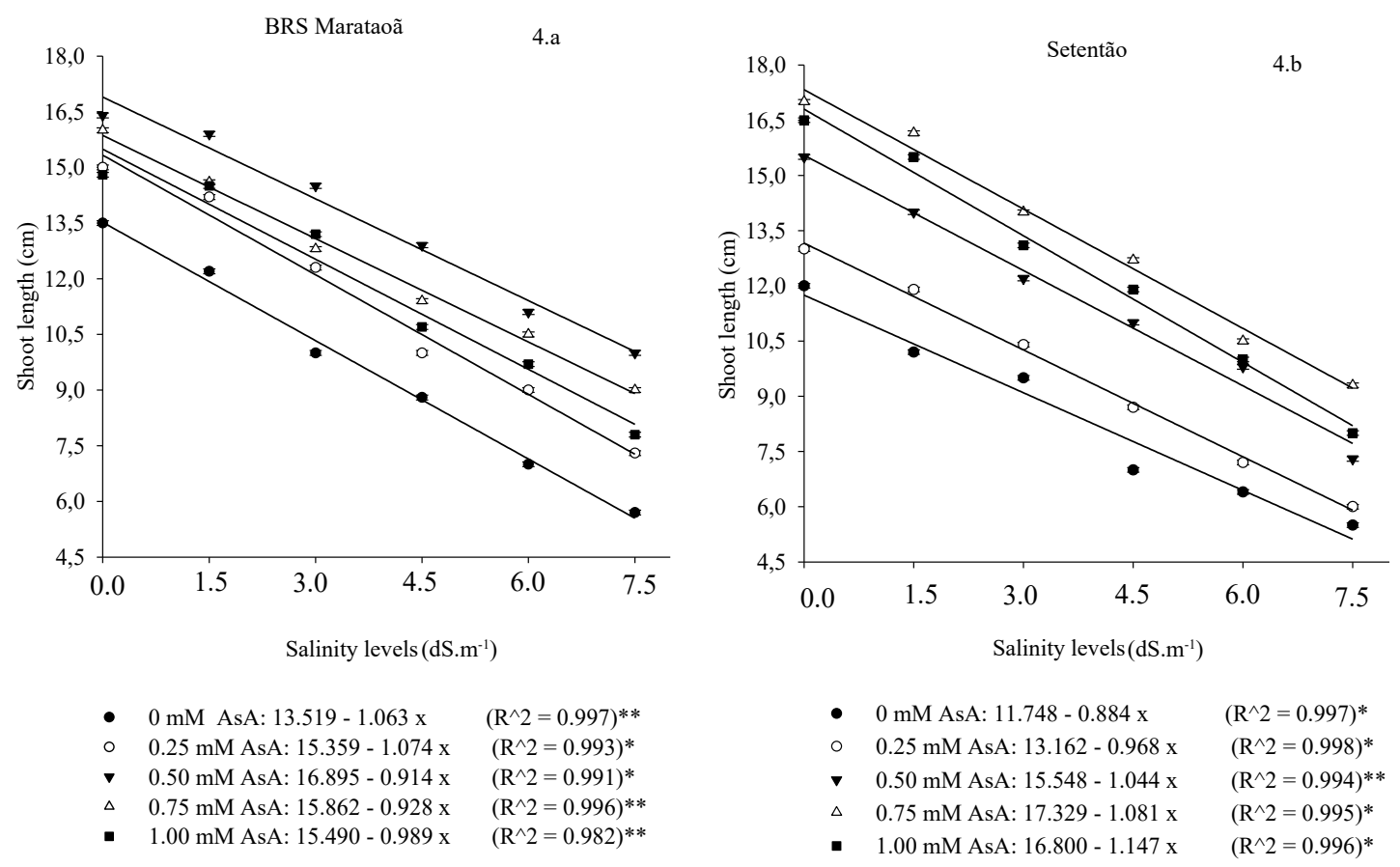

Figure 4. Shoot length of cowpea genotype seedlings at different saline levels and conditioned with ascorbic acid. *Significant at $5 \%$;

$* *$ Significant at $1 \%$. 
concentration (100 mM NaCl - 10 dS.m $\left.{ }^{-1}\right)$ in comparison to control. Growth inhibition may occur because of the toxic effect of ions, and also as a result of decreased water potential, which affects water absorption kinetics, producing physiological drought (Deuner et al., 2011).

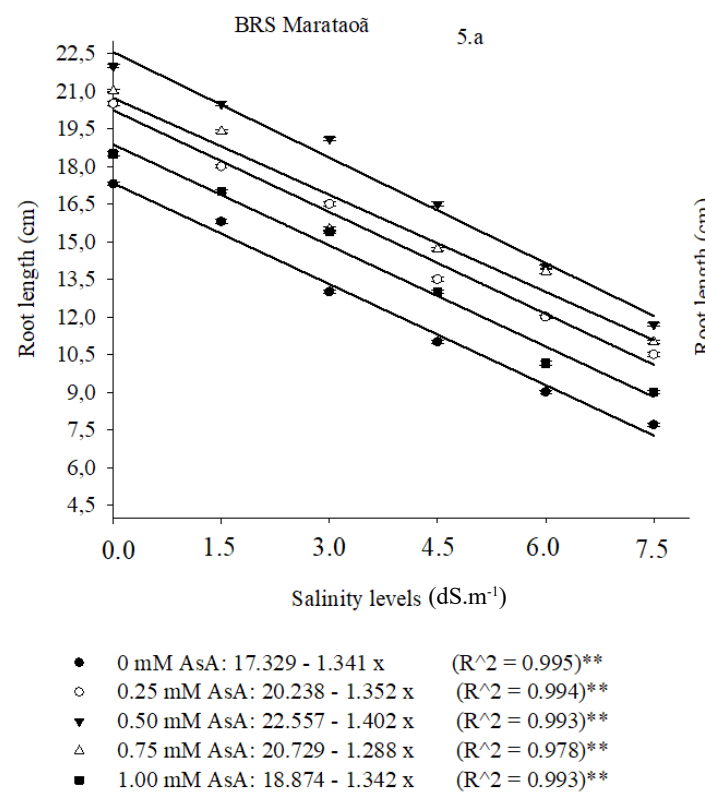

At higher concentrations, salt stress caused a reduction in seedling dry weight for both cowpea genotypes (Figure 6), with the highest values found at concentrations of $0.50 \mathrm{mM}$ for BRS Marataoã and 0.75 for Setentão, with approximately 85 and $80 \mathrm{mg}^{-1}$, respectively. This factor is attributed to the

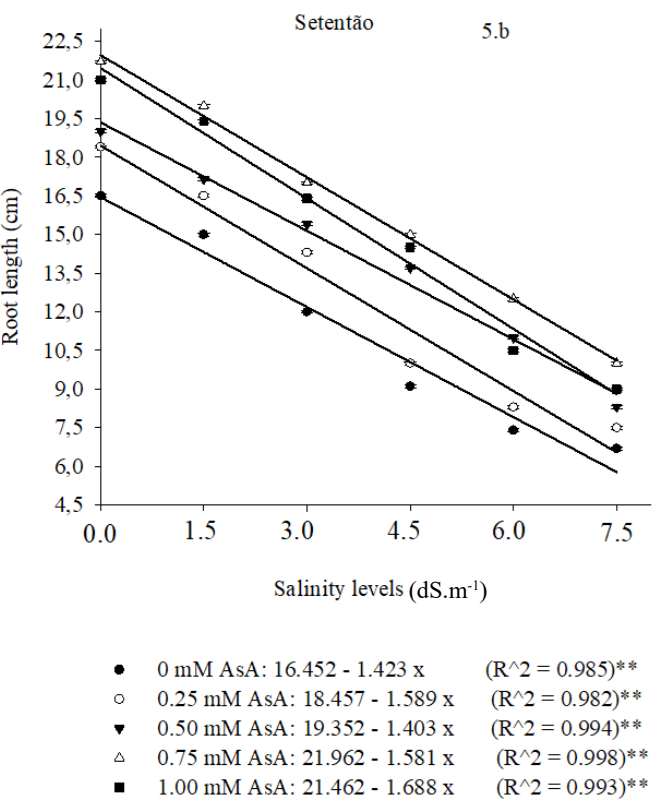

Figure 5. Root length of cowpea seedlings at different saline levels and conditioned with ascorbic acid.

* Significant at $5 \%$;

***ignificant at $1 \%$.

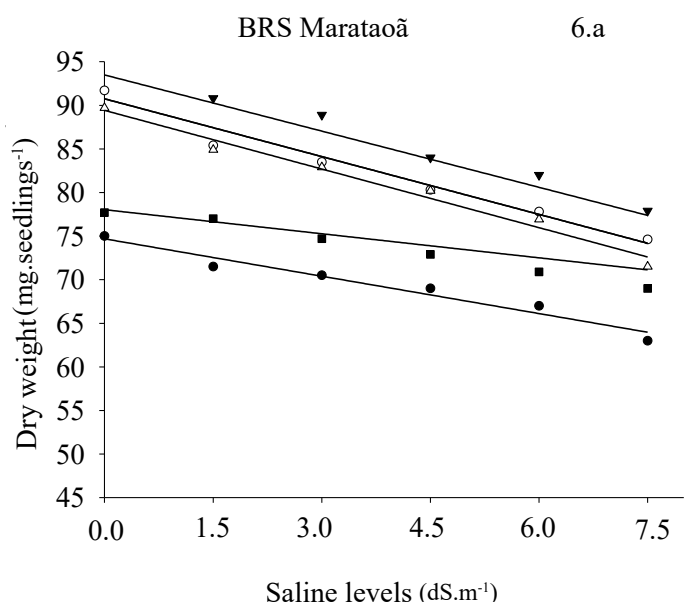

- 0 mM AsA: $74.690-1.429 \mathrm{x}$

$0.25 \mathrm{mM}$ AsA: $90.752-2.210 \mathrm{x}$

จ $\quad 0.50 \mathrm{mM}$ AsA: $95.930-2.320 \mathrm{x}$

$\Delta \quad 0.75$ mM AsA: $89.424-2.242 \mathrm{x}$

- $\quad 1.00 \mathrm{mM}$ AsA: $78.243-1.211 \mathrm{x}$

$$
\begin{aligned}
& \left(\mathrm{R}^{\wedge} 2=0.979\right)^{* *} \\
& \left(\mathrm{R}^{\wedge} 2=0.958\right)^{* *} \\
& \left(\mathrm{R}^{\wedge} 2=0.959\right)^{* *} \\
& \left(\mathrm{R}^{\wedge} 2=0.989\right)^{* *} \\
& \left(\mathrm{R}^{\wedge} 2=0.947\right)^{* *}
\end{aligned}
$$

Figure 6. Dry weight of cowpea seedlings at different saline levels and conditioned with ascorbic acid.

*Significant at $5 \%$;

**Significant at $1 \%$. 
supply of cotyledon reserves to primary plant, root and stem structures (Dalchiavon et al., 2016).

In cowpea irrigated with electric conductivity water at $2.2 \mathrm{dS} . \mathrm{m}^{-1}$ or higher, Bezerra et al. (2010) found lower values for dry weight of leaves, stem, pods and shoots. In lima beans, Dalchiavon et al. (2016) mentioned that saline stress reduces the nutritional reserve capacity of seeds, and, consequently, leads to lighter seedlings. The weight found at high saline concentrations ranged from 121 to $132 \mathrm{mg}$, whereas for the control, it ranged between 171 and 195 mg.seedling ${ }^{-1}$. However, Deuner et al. (2011) stated that in Vigna radiata plants, rates up to $150 \mathrm{mM} \mathrm{NaCl}$ increased stem dry weight, while the same result was found for leaves up to the rate of $100 \mathrm{mM}$.

Saline treatments caused an increase in membrane damage, based on electrolyte leakage, in the leaf and root tissues of genotypes Marataoã and Setentão. At the highest saline concentration, electrolyte release in these tissues increased about 1.2-fold compared to the respective controls (Figures $7 \mathrm{~A}$ and $7 \mathrm{~B}$ ), with the root system releasing more
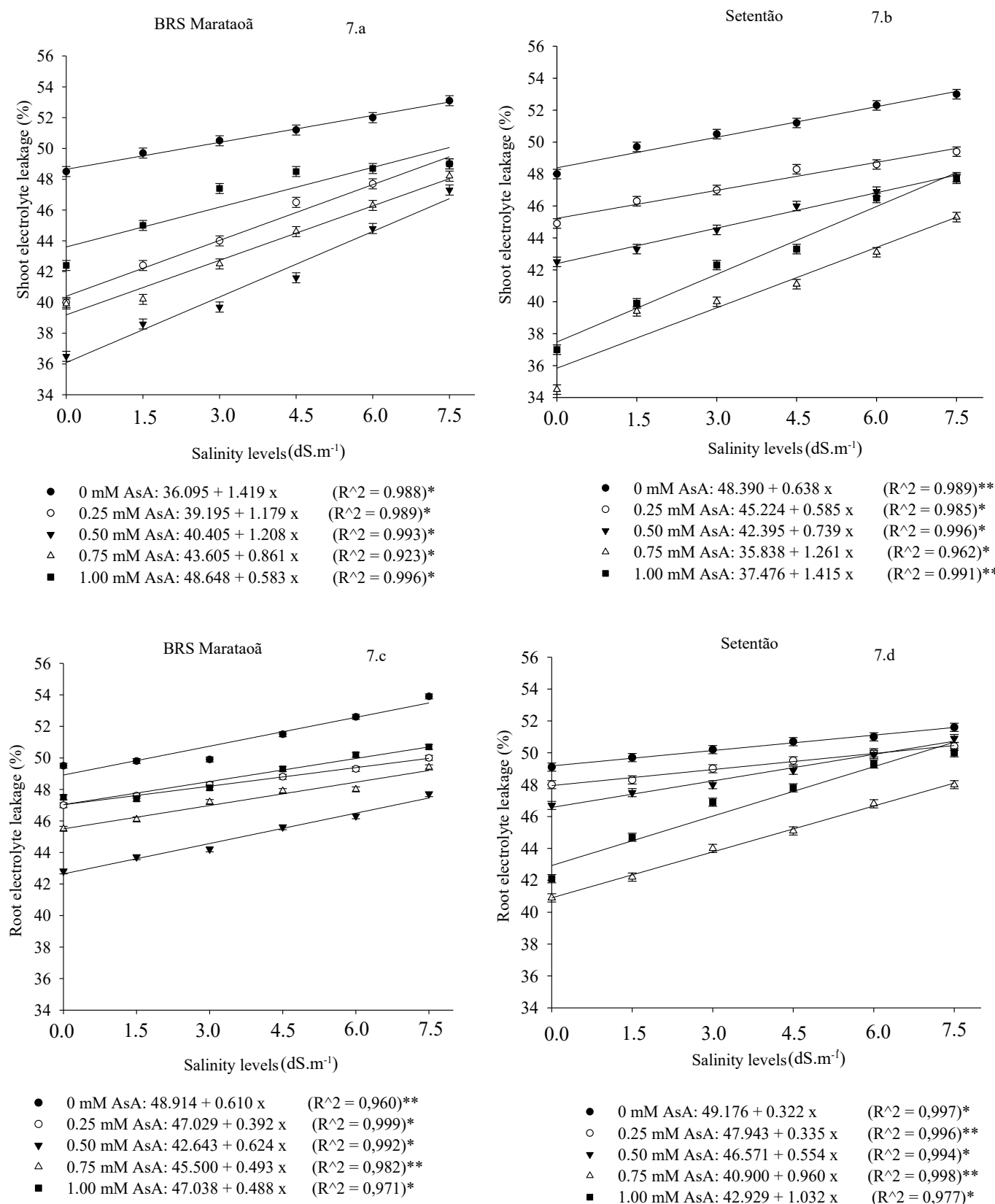

Figure 7. Electrolyte leakage in cowpea leaf and root tissues at different saline levels and conditioned with ascorbic acid. *Significant at 5\%;

**Significant at $1 \%$. 
electrolytes compared to leaves (Figures 7C and 7D). These results corroborate those found by Maia et al. (2012), in cowpea cultivars Pérola and Pitiúba. They found a three-fold increase at the highest concentration $(100 \mathrm{mM}$, approximately $\left.10 \mathrm{dS} . \mathrm{m}^{-1}\right)$ in comparison to control.

Saline stress, like other abiotic stress factors, induces oxidative damage to plant cells catalyzed by reactive oxygen species (ROS); when plants are exposed to such situations, they need to develop defense mechanisms capable of perceiving the stimulus, generate and transmit signals and instigate biochemical changes to adjust their metabolism. In general, they cannot produce enough natural antioxidants to mitigate this damage; consequently, there are reductions in the parameters of development and production, as found in the variables analyzed in this work for seeds not treated with AsA.

Conditioning with ascorbic acid led to an increase in the defense mechanism of cowpea seedlings against salinity. When the concentration of $0.50 \mathrm{mM}$ AsA was used in the seeds of genotype BRS Marataoã, there was less membrane damage at the highest saline concentration $\left(7.5 \mathrm{dS} . \mathrm{m}^{-1}\right)$ in comparison to the control treatment in both the leaves and the root system. The other AsA concentrations also caused reductions in electrolyte leakage (Figures 7A and 7C). For genotype Setentão, all tested values of AsA were lower than those found in the untreated seeds. In the control treatment, the values of $48.00 \%$ and $49.50 \%$ were found; when the seeds were treated with $0.75 \mathrm{mM}$ AsA and exposed to 7.5 $\mathrm{dS} . \mathrm{m}^{-1}$, there was a reduction in these values, which were around $45.30 \%$ and $48.00 \%$ for leaves and roots, respectively (Figures 7B and 7D).

This reduction is due to the great importance of ascorbic acid to plants, because it is considered as a key substance to the antioxidant mechanism, and it is essential for the synthesis of a series of antioxidant enzymes (Khan et al., 2011). It protects macromolecules from oxidative damage caused by hydroxyl, superoxide and singlet oxygen radicals (Dehghan et al., 2011).

\section{Conclusions}

The conditioning of cowpea seeds with ascorbic acid at concentrations of $0.50 \mathrm{mM}$ for genotype BRS Marataoã and $0.75 \mathrm{mM}$ for genotype Setentão, enabled the development of more vigorous seedlings and reduced membrane damage caused by oxidative stress, both in the absence of salt and at the saline levels tested, including the highest one $\left(7.5 \mathrm{dS} \cdot \mathrm{m}^{-1}\right)$.

\section{References}

APEL, K.; HIRT, H. Reactive oxygen species: metabolism, oxidative stress and signal transduction. Annual Review of Plant Biology, v.55, p.373-399, 2004. https://www.annualreviews.org/doi/10.1146/ annurev.arplant.55.031903.141701

AZOOZ, M.M.; Al-FREDAN, M.A. The inductive role of vitamin $\mathrm{C}$ and its mode of application on growth, water status, antioxidant enzyme activities and protein patterns of Vicia faba L. cv. Hassawi grow under seawater irrigation. American Journal of Plant Physiology, v.4, n.1, p.38-51, 2009. https://scialert.net/ abstract/?doi=ajpp.2009.38.51

BEZERRA, A.K.P.; LACERDA, C.F.; HERNANDEZ, F.F.F.; SILVA, F.B.; GHEYI, H.R. Rotação cultural feijão caupi/milho utilizando-se águas de salinidades diferentes. Ciência Rural, v.40, n.5, p.10751082, 2010. http://dx.doi.org/10.1590/S0103-84782010000500012

BRASIL. Ministério da Agricultura, Pecuária e Abastecimento. Regras para análise de sementes. Ministério da Agricultura, Pecuária e Abastecimento. Secretaria de Defesa Agropecuária. Brasília: MAPA/ACS, 2009. 395p. http:// www.agricultura.gov.br/ arq_editor/file/2946_regras_analise_sementes.pdf

BRILHANTE, J.C.A.; OLIVEIRA, A.B.; SILVA, J.W.L.; ENÉASFILHO, J. Ação do ácido ascórbico exógeno na qualidade fisiológica de sementes de feijão de corda envelhecidas artificialmente. Semina: Ciências Agrárias, v.34, n.3, p.985-994, 2013. http://www.uel.br/ revistas/uel/index.php/semagrarias/article/view/9969

CARVALHO, T.C.; SILVA, S.S.; SILVA, R.C; PANOBIANCO, M. Germinação e desenvolvimento inicial de plântulas de soja convencional e sua derivada transgênica RR em condições de estresse salino. Ciência Rural, v.42, n.8, p.1366-1371, 2012. http:// dx.doi.org/10.1590/S0103-84782012000800006

ÇAVUSOGLU, K.; BILIR, G. Effects of ascorbic acid on the seed germination, seedling growth and leaf anatomy of barley under salt stress. Journal of Agricultural and Biological Science, v. 10, n.4, p.124-129, 2015. http://www.arpnjournals.com/jabs/research papers/rp_2015/jabs_0415_720.pdf

CONUS, L.A.; CARDOSO, P.C.; VENTUROSO, L.R.; SCALON, S.P.Q. Germinação de sementes e vigor de plântulas de milho submetidas ao estresse salino induzido por diferentes sais. Revista Brasileira de Sementes, v.31, n.4, p.67-74, 2009. http://dx.doi. org/10.1590/S0101-31222009000400008

DALCHIAVON, F.C.; NEVES, G.; HAGA, K.I. Efeito de estresse salino em sementes de Phaseolus vulgaris. Revista de Ciências Agrárias, v.39, n.3, p.404-412, 2016. http://dx.doi.org/10.19084/ RCA15161

DAWOOD, M.G.; EL-AWADI, M.E.S.; ABDEL-BAKY, Y.R.; SADAK, M.S. Physiological role of ascobin on sunflower plants irrigated with sodium chloride solution. Agricultural Engineering International, Special issue, p.16-26, 2017. http:/www.cigrjournal. org/index.php/Ejounral/article/view/4375/2641

DEHGHAN, G.; REZAZADEH, L.; HABIBI, G. Exogenous ascorbate improves antioxidant defense system and induces salinity tolerance in soybean seedlings. Acta Biologica Szegediensis, v.55, n.2, p.261-264, 2011. https://www2.sci.u-szeged.hu/ABS/2011/Acta\%20HPb/55261.pdf 
DEUNER, C.; MAIA, M.S.; DEUNER, S.; ALMEIDA, A.S.; MENEGHELLO, G.E. Viabilidade e atividade antioxidante de sementes de genótipos de feijão-miúdo submetidos ao estresse salino. Revista Brasileira de Sementes, v.33, n.4, p.711-720, 2011. http://www.scielo.br/pdf/rbs/v33n4/13.pdf

FERREIRA, A.C.T.; FELITO, R.A.; ROCHA, A.M.; CARVALHO, M.A.C.; YAMASHITA, O.M. Water and salt stresses on germination of cowpea (Vigna unguiculata cv. BRS Tumucumaque) seeds. Revista Caatinga, v.30, n.4, p.1009-1016, 2017. http://dx.doi. org/10.1590/1983-21252017v30n422rc

FERREIRA, D.F. Análises estatísticas por meio do Sisvar para Windows versão 4.0. In: Reunião Anual da Região Brasileira da Sociedade Internacional de Biometria. São Carlos, SP: SIB, 2000. p.255-258.

FREIRE, F.R.F.F.; VILARINHO, A.A.; CRAVO, M.S.; CAVALCANTE, E.S. Panorama da cultura do feijão-caupi no Brasil. In: Workshop sobre a Cultura do Feijão-Caupi em Roraima. Boa Vista: Embrapa Roraima, 2007. p.11-14. https://www.alice.cnptia. embrapa.br/handle/doc/347668

FREIRE-FILHO, F.R.; RIBEIRO, V.Q.; ROCHA, M.M.; SILVA, K.J.D.; NOGUEIRA, M.S.R.; RODRIGUES, E.V. Feijão-caupi no Brasil: produção, melhoramento genético, avanços e desafios. $1^{\text {a }}$ ed. Teresina, PI: Embrapa Meio-Norte, 2011. 84p.

GAD EL-HAK, S.H.; AHMED, A.M.; MOUSTAFA, Y.M.M. Effect of foliar application with two antioxidants and humic acid on growth, yield and yield components of peas (Pisum sativum L.). Journal of Horticultural Science amd Ornamental Plants, v.4, p.318-328, 2012. https://www.researchgate.net/publication/233884938_Effect_of_ Foliar_Application_with_Two_Antioxidants_and_Humic_Acid_on_Growth_Yield_and_Yield_Components_of_Peas_Pisum_sativum_L

GOMES, G.R.; ALMEIDA, L.H.C.; TAKAHASHI, L.S.A. Efeito do estresse hídrico e salino no vigor e germinação de sementes de feijãovagem (Phaseolus vulgaris L.). Cultura Agronômica, v.24, n.1, p.8392, 2015. http://ojs.unesp.br/index.php/rculturaagronomica/article/ view/2304/1717

ISHIBASHI, Y.; IWAYA-INOUE, M. Ascorbic acid suppresses germination and dynamic states of water in wheat seeds. Plant Production Science, v.9, n.2, p.172-175, 2006. https://doi. org/10.1626/pps.9.172

KHAN, T.A.; MAZID, M.; MOHAMMAD, F. A review of ascorbic acid potentialities against oxidative stress induced in plants. Journal of Agrobiology, v.28, n.2, p.97-111, 2011. https://doi.org/10.2478/ v10146-011-0011-x

MAIA, J.M.; FERREIRA-SILVA, S.L.; VOIGT, E.L.; MACÊDO, C.E.C.; PONTE, L.F.A.; SILVEIRA, J.A.G. Atividade de enzimas antioxidantes e inibição do crescimento radicular de feijão caupi sob diferentes níveis de salinidade. Acta Botânica Brasílica, v.26, n.2, p.342349, 2012. http://dx.doi.org/10.1590/S0102-33062012000200010

MAGUIRE,J.D.Speedofgermination-aidinselectionandevaluationfor seedling emergence and vigor. Crop Science, v.2, n.1, p.176-177, 1962. http://dx.doi.org/10.2135/cropsci1962.0011183X000200020033x
MONDO, V.H.V.; CARVALHO, S.J.P.; DIAS, A.C.R.; MARCOSFILHO, J. Efeitos da luz e temperatura na germinação de sementes de quatro espécies de plantas daninhas do gênero Digitaria. Revista Brasileira de Sementes, v.32, n.1, p.131-137, 2010. http://dx.doi. org/10.1590/S0101-31222010000100015

MUNNÉ-BOSCH, S.; QUEVAL, G; FOYER, C.H. The impact of global change factors on redox signaling underpinning stress tolerance. Plant Physiology, v.161, n.1, p.5-19, 2013. https://doi. org/10.1104/pp.112.205690

NASCIMENTO, M.G.R.;ALVES, E.U.; SILVA, M.L.M.; RODRIGUES, C.M. Lima bean (Phaseolus lunatus L.) seeds exposed to different salt concentrations and temperatures. Revista Caatinga, v.30, n.3, p.738-747, 2017. http://dx.doi.org/10.1590/1983-21252017v30n322rc

PINHEIRO, G.G.; ZANOTTI, R.F.; PAIVA, C.E.C.; LOPES, J.C.; GAI, Z.T. Efeito do estresse salino em sementes e plântulas de feijão-guandu. Enciclopédia Biosfera, v.9, n.16, p.901-912, 2013. http://www.conhecer.org.br/enciclop/2013a/agrarias/Efeito\%20 do $\% 20$ estresse $\% 20$ salino.pdf

RAZA, S.H.; SHAFIQ, F.; CHAUDHARY, M. Seed invigoration with water, ascorbic and salicylic acid stimulates development and biochemical characters of okra (Ablemoschus esculentus) under normal and saline conditions. International Journal of Agriculture and Biology, v.15, n.3, p.486-492, 2013. http://agris.fao.org/agrissearch/search.do?recordID $=$ PK2013000720

RICHARDS, L.A. Diagnosis and improvement of saline and alkali soils. Agricultural Handbook, 60. ed. Washington D.C.: U.S. Department of Agriculture, 1954. 160p. https://www.ars.usda.gov/ ARSUserFiles/20360500/hb60_pdf/hb60complete.pdf

SOARES, M.M.; SANTOS-JÚNIOR, H.C.; SIMÕES, M.G.; PAZZIN, D.; JUNIO DA SILVA, L. Estresse hídrico e salino em sementes de soja classificadas em diferentes tamanhos. Pesquisa Agropecuária Tropical, v.45, n.4, p.370-378, 2015. http://dx.doi. org/10.1590/1983-40632015v4535357

TAIZ, L.; ZEIGER, E.; MOLLER, I.; MURPHY, A. Fisiologia e desenvolvimento vegetal. $6^{\mathrm{a}}$ ed. Porto Alegre: Artmed, 2017. 888p.

TALLA, S.; RIAZUNNISA, K.; PADMAVATHI, L.; SUNIL, B.; RAJSHEEL, P.; RAGHAVENDRA, A.S. Ascorbic acid is a key participant during the interactions between chloroplasts and mitochondria to optimize photosynthesis and protect against photoinhibition. Journal of Biosciences, v.36, n.1, p.163-173, 2011. https://www.ncbi.nlm.nih.gov/pubmed/21451257

TARHANEN, S.; METSARINNE, S.; HOLOPAINEN, T.; OKSANEN, J. Membrane permeability response of lichen Bryoria fuscescens to wet deposited heavy metals and acid rain. Environmental Pollution, v.104, n.1, p.121-129, 1999. https://doi. org/10.1016/S0269-7491(98)00157-2

WILLADINO, L.; CAMARA, T.R. Tolerância das plantas à salinidade: aspectos fisiológicos e bioquímicos. Enciclopédia Biosfera, v.6, n.11, p.1-23, 2010. http://www.conhecer.org.br/ enciclop $/ 2010 \mathrm{c} /$ tolerancia $\% 20$ das $\% 20$ plantas.pdf 
XU, J.; TRAN, T.; PADILLA MARCIA, C.S.; BRAUN, D.M.; GOGGIN, F.L. Superoxide-responsive gene expression in Arabidopsis thaliana and Zea mays. Plant Physiology and Biochemistry, v.117, p.51-60, 2017. https://www.sciencedirect.com/ science/article/pii/S0981942817301754

YU, S.; WANG, W.; WANG, B. Recent progress of salinity tolerance research in plants. Russian Journal of Genetics, v.48, n.5, p.497-505, 2012. https://www.ncbi.nlm.nih.gov/pubmed/22830254
ZHANG, Y. Ascorbic Acid in plants: Biosynthesis, regulation and enhancement. $1^{\mathrm{a}}$ ed. New York: Springer-Verlag, 2013. 117p.

This is an Open Access article distributed under the terms of the Creative Commons Attribution License, which permits unrestricted use, distribution, and reproduction in any medium, provided the original work is properly cited. 